\title{
Nutrition Knowledge, Dietary Pattern, and Nutritional Status of Elementary Students in Makassar City
}

\author{
Pengetahuan Gizi, Pola Makan, dan Status Gizi Siswa Sekolah Dasar \\ di Kota Makassar
}

\author{
Syarfaini $^{*}$, Eka S. Ridwan ${ }^{2}$, Syahratul Aeni ${ }^{3}$ \\ ${ }^{1,3}$ Bagian Kesehatan Masyarakat, Universitas Islam Negeri Alauddin Makassar, Makassar \\ ${ }^{2}$ Department of Health Education and Behavioral Sciences, Mahidol University, Thailand
}

DOI: $10.24252 /$ al-sihah.v13i1.21239

Received: 1 June 2021 / In Reviewed: 7 June 2021 / Accepted: 27 June 2021 / Available online: 30 June 2021 (C) The Authors 2021. This is an open access article under the CC BY-NC-SA 4.0 license

\begin{abstract}
Elementary school children are a vulnerable group to nutritional problems. Malnutrition is generally caused by poverty, lack of food supplies, poor environmental quality, lack of public knowledge about nutrition, a balanced diet, and health. The purpose of this study was to analyze the relationship between balanced nutrition knowledge, dietary pattern, and nutritional status of children in Sekolah Dasar Islam Terpadu (SDIT) Makassar, Indonesia. The population in this study were all students in grades 4 and 5 with a total sample of 94 people. The results showed that there was no relationship between balanced nutrition knowledge and nutritional status $(P=0.397)$ and there was no relationship between diet pattern and nutritional status $(P$ $=0.662)$ children at SDIT Makassar. Researchers recommend a Balanced Nutrition Ambassador program in every school. Ambassadors of Balanced Nutrition will be trained related to balanced nutrition and is responsible for disseminating balanced nutrition messages to their friends and their family.
\end{abstract}

\begin{abstract}
ABSTRAK
Anak usia Sekolah Dasar merupakan kelompok rentan akan masalah gizi. Permasalahan gizi pada umumnya diakibatkan oleh beberapa faktor seperti kemiskinan, kualitas lingkungan yang buruk, pengetahuan yang kurang mengenai gizi seimbang dan kesehatan. Tujuan penelitian ini untuk melihat hubungan antara pola makan dan pengetahuan mengenai gizi seimbang terhadap status gizi anak di Sekolah Dasar Islam Terpadu (SDIT) di Kota Makassar, Indonesia. Populasi dalam penelitian ini merupakan seluruh siswa yang berada di kelas 4 dan 5 dengan total sampel sebanyak 94 orang. Hasil penelitian menunjukkan bahwa tidak ada hubungan antara pengetahuan gizi seimbang dengan status gizi $(\mathrm{P}=0,397)$ dan tidak ada hubungan antara pola makan dengan status gizi $(\mathrm{P}=0,662)$ pada anak di Sekolah Dasar SDIT Makassar. Peneliti menawarkan adanya program duta gizi seimbang di setiap sekolah. Duta gizi seimbang ini nantinya akan dilatih terkait gizi seimbang dan bertanggungjawab mensosialisasikan pesan-pesan gizi seimbang kepada teman sekolah, maupun di keluarga.
\end{abstract}

\section{GRAPHICAL ABSTRACT}

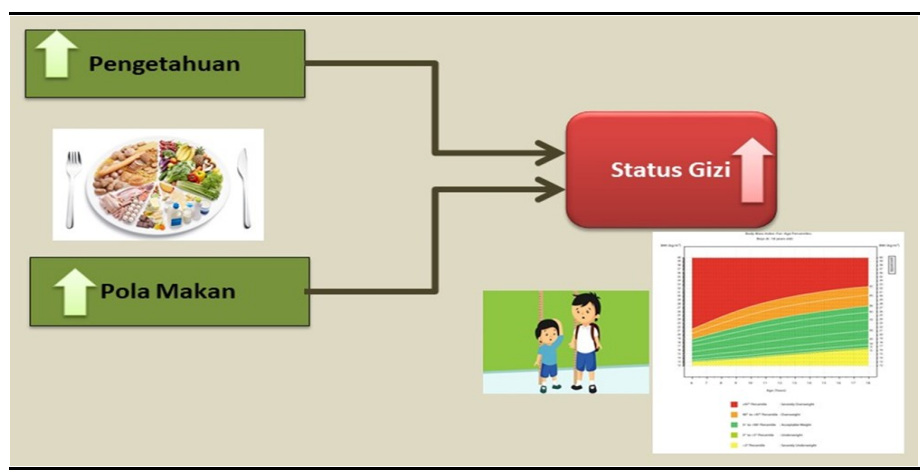

Keyword

balanced nutrition knowledge; diet pattern; elementary students; nutritional status

\section{Kata Kunci:}

pola makan; pengetahuan gizi seimbang; siswa sekolah dasar; status gizi

\section{* Correspondence}

Perumahan Bukit Khatulistiwa Blok L No.24

Makassar

Email: syarfaini.suyuti@uin-alauddin.ac.id 


\section{PENDAHULUAN}

Gizi merupakan indeks dalam penilaian kesuksesan program kesehatan suatu negara dalam meningkatkan sumber daya manusia yang berkualitas (Cuenca et al., 2020). Adanya keseimbangan antara asupan dan kebutuhan akan zat gizi merupakan status gizi optimal (Calder et al., 2020). Persoalan gizi merupakan bagian dari perkara dalam bidang kesehatan yang ada di Indonesia (Pattola et al., 2020). Data menunjukkan pada tahun 2015 status gizi anak kurus dunia sekitar 13,9\%, atau sebanyak 93,4 juta (World Health Organization, 2016). Anak usia sekolah adalah masa transisi dari anak-anak menjadi dewasa, pada saat ini perkembangan mental, fisik, dan emosionalnya sangat pesat. Anak usia sekolah mulai menganggap serius pengungkapan ide, menjadi lebih objektif, dan mulai menerima hal-hal baru untuk observasi dan mendengarkan (Amrah, 2013). Pada usia ini, anak-anak lebih banyak beraktivitas di sekolah dan di luar sekolah, sehingga anak membutuhkan lebih banyak energi bergantung pada jumlah makanan yang dimakan anak, pertumbuhan anak lambat tapi pasti (Liszewska et al., 2018; Al Yazeedi et al., 2021). Pada masa ini juga merupakan masa peralihan yang dimana anak sekolah dasar merupakan fase menuju masa berikutnya yaitu masa pubertas, sehingga peranan zat gizi sangat diperlukan guna mengoptimalkan pertumbuhan (Lonto et al., 2019)

Riset Kesehatan Dasar (Riskesdas) 2013 mengeluarkan data status gizi anak usia 5-12 tahun berdasarkan IMT/umur dengan prevalensi kurus sebesar 11,2\%.
Terdapat $18,8 \%$ masalah gemuk pada anak yang terdiri dari kategori gemuk hingga obesitas. Selain itu, sebanyak 30,7\% anak yang dikategorikan pendek. Adapun di Provinsi Sulawesi Selatan berdasarkan data Riskesdas 2013, anak usia 5-12 yang mengalami masalah gizi masih cukup tinggi, dengan $11 \%$ yang terdiri dari $4 \%$ sangat kurus dan 7\% kategori kurus. Adapun masalah kegemukan di Sulawesi Selatan memiliki prevalensi sebesar $14,6 \%$ yang terdiri atas $8,7 \%$ kategori gemuk dan 5,9\% obesitas (Kementerian Kesehatan RI, 2014).

Buruknya pola makan sejak kanakkanak banyak yang terbawa hingga dewasa mengakibatkan mereka rentan menderita berbagai penyakit degeneratif terkait dengan nutrisi, seperti penyakit jantung dan pembuluh darah, kanker atau diabetes melitus (Donin et al., 2018; Corvalán et al., 2017; Pereira et al., 2014) . Riset Kesehatan Dasar 2013 menunjukkan, prevalensi penderita diabetes telah mencapai 2,1\%, kanker $1,4 \%$ jantung koroner 1,5\%, dan stroke 12,4\% (Kementerian Kesehatan RI, 2014). Usia dini merupakan waktu yang tepat untuk pencegahan malnutrisi (Ijarotimi, 2013; Tette et al., 2015). Hal ini merupakan salah satu bentuk upaya strategis untuk mendapatkan manfaat jangka panjang dan jangka pendek dengan penerapan pendidikan kesehatan pada usia dini. Bentuk upaya yang dapat diterapkan adalah dengan pembinaan perilaku pola gizi seimbang berbasis sekolah dalam rangka meningkatkan prevalensi status gizi yang baik dan mengurangi tingkat prevalensi dan mewujudkan Sumber Daya Manusia (SDM) yang baik. Pendidikan kesehatan merupakan langkah awal un- 
tuk menuju perilaku hidup sehat dengan adanya perubahan perilaku seseorang atau masyarakat (Kumar \& Preetha, 2012).

Anak usia sekolah dasar sendiri merupakan tumpuan dalam proses pembelajaran. Umumnya orang tua, komunitas ataupun lingkungan sekolah memiliki pengaruh dalam membentuk pola makan pada anak, mereka mudah terpapar dengan jajanan yang menarik di sekolah dan mereka mampu membelinya. (Passos et al., 2015). Badan Kesehatan Dunia (WHO) biasanya merekomendasikan 400 gram sayur dan buah per orang per hari untuk menjaga kesehatan, di antaranya 250 gram sayur mayur dan 150 gram buah-buahan. Bayi berusia di bawah lima tahun dan anak usia sekolah dianjurkan mengonsumsi 300400 gram sayur dan buah per hari, serta remaja dan dewasa 400-600 gram per hari, hal ini dikhususkan bagi masyarakat Indonesia. Sekitar dua pertiga konsumsi sayuran dari total konsumsi buah-buahan dan sayur-mayur. Data dari Riskesdas dari tahun 2007 ke 2013 terkait perilaku kurangnya konsumsi sayur-sayuran dan buahbuahan tidak memperlihatkan adanya perubahan yang signifikan dengan besaran $93,6 \%$ menjadi $93,5 \%$ yang berarti hanya mengalami penurunan $0,1 \%$. Provinsi Sulawesi Selatan mengumpulkan data yang sama pada tahun 2007 dan 2013 yaitu mengenai proporsi penduduk usia $\geq 10$ tahun dengan tingkat konsumsi sayursayuran dan buah-buahan yang masih rendah. Berdasarkan data Riskesdas 2013 didapatkan bahwa di terjadi peningkatan yang cukup signifikan di Provinsi Sulawesi Selatan yaitu dari angka 93,7\% menjadi
96\% yang menandakan konsumsi sayur dan buah yang masih sangat rendah (Kementerian Kesehatan RI, 2014).

Riset Kesehatan Dasar di Provinsi Sulawesi Selatan tahun 2013 menunjukkan bahwa penduduk umur 10 tahun ke atas di Kota Makassar kurang mengonsumsi sayur dan buah dengan prevalensi sebesar 98,5\%. Berbagai penelitian juga menunjukkan adanya pengaruh gaya hidup modern terhadap perilaku hidup sehat anak usia sekolah dasar (Mavrovouniotis, 2012; Bagchi, 2014; Ali et al., 2020). Hal ini dibuktikan dengan adanya perilaku jajan yang tidak sehat dan kurangnya aktivitas fisik merupakan fenomena yang lebih banyak terjadi pada siswa sekolah. Hal ini dibuktikan dengan hasil dari Riset Kesehatan Dasar tahun 2013 menunjukkan bahwa masalah gizi berlebih masih tinggi pada anak usia 6-12 tahun dengan 10,8 di antaranya kategori gemuk dan 8,8\% kategori obesitas (sangat gemuk) (Kementerian Kesehatan RI, 2014). Tanpa usaha yang serius, semua hal tersebut bisa berdampak terhadap lahirnya keturunan dengan kesehatan yang buruk dan berisiko menderita berbagai gangguan kesehatan.

Beberapa penelitian telah dilakukan sebelumnya tentang pengaruh pengetahuan dengan gizi anak sekolah (Fajriani et al., 2020; Fadila et al., 2017; Couteau, 2020; Irnani \& Sinaga; 2017). Melihat data Riskesdas di Kota Makassar menunjukkan tingginya prevalensi kurang mengonsumsi sayur bagi anak usia sekolah maka peneliti ingin melihat hubungan antara pola makan dan pengetahuan mengenai gizi seimbang terhadap status gizi anak di Sekolah Dasar 
Tabel 1

Distribusi Karakteristik Responden

\begin{tabular}{lcc}
\hline Karakteristik & $\mathrm{N}$ & $\%$ \\
\hline Jenis Kelamin & 37 & 39,4 \\
$\quad$ Laki-laki & 57 & 60,6 \\
Perempuan & & \\
Umur Responden & 7 & 7,4 \\
8 tahun & 50 & 53,2 \\
9 tahun & 34 & 36,2 \\
10 tahun & 2 & 2,1 \\
11tahun & 1 & 0,6 \\
12 tahun & & \\
Pendidikan ayah & 13 & 13,8 \\
Tamat SMP & 2 & 2,1 \\
Tamat SMA & 15 & 16 \\
Tamat Akademi D1/D2 & 64 & 68,1 \\
Tamat Perguruan Tinggi S1/S2/S3 & & \\
Pendidikan Ibu & 1 & 1,1 \\
Tamat SMP & 28 & 29,8 \\
Tamat SMA & 11 & 11,7 \\
Tamat Akademi D1/D2 & 54 & 57,4 \\
Tamat Perguruan Tinggi S1/S2/S3 & & \\
Pekerjaan Ayah & 7 & 7,4 \\
TNI/Polri & 33 & 35,1 \\
PNS & 30 & 30 \\
Pegawai Swasta & 19 & 19 \\
Wraswasta & 5 & 5 \\
Lainnya & & \\
Pekerjaan Ibu & 11 & 11,7 \\
Tidak bekerja (IRT) & 81 & 1,1 \\
PNS & 1 & 1,1 \\
Pegawai Swasta & 1 & \\
Lainnya & & \\
& & \\
\hline
\end{tabular}

Islam Terpadu (SDIT) sekota Makassar yang diharapkan mampu mencakup banyak sampel dan lebih komprehensif.

\section{METODE PENELITIAN}

Penelitian ini merupakan rancangan kuantitatif dengan menggunakan pendekatan cross-sectional. Penelitian dilaksanakan di Sekolah Dasar Islam Terpadu (SDIT) Kota Makassar sebanyak 11 SDIT yang bersedia berpartisipasi menjadi responden penelitian selama 4 minggu. Populasi dalam penelitian ini adalah seluruh siswa kelas 4 dan 5 Sekolah Dasar Islam Terpadu Kota Makassar sebanyak 1815 orang. Adapun total sampel dalam penelitian ini sebanyak 94 responden yang dihitung menggunakan rumus slovin dengan kesalahan yang ditoleransi (0.1). Multi Stage Sampling merupakan metode pengambilan sampel dalam penelitian ini.

Instrumen yang digunakan penelitian ini berupa lembar kuesioner dengan identitas responden, pengetahuan gizi seimbang, dan form pengukuran antropometri anak. Instrumen lain yang 
digunakan adalah Food Frequency untuk menilai gambaran pola makan responden. Data berat badan anak diambil dengan menggunakan timbangan dan data tinggi badan anak diambil dengan menggunakan Microtoice.

Pengolahan dan analisis data pada variabel pengetahuan gizi seimbang dikategorikan menjadi cukup/kurang berdasarkan skoring nilai median dari pengetahuan responden tentang makanan, pemilihan dan konsumsi bahan makanan yang dibutuhkan fungsi normal tubuh berdasarkan pilar gizi seimbang. Pada variabel pola makan menggunakan Food Frequency Questionnaire (FFQ) dengan katagori baik/kurang berdasarkan nilai mean. Adapun variabel status gizi menggunakan aplikasi program WHO Anthro Plus dengan kriteria ; Sangat Kurus: >-3 SD, Kurus: -3 SD sampai dengan -2 SD, Normal: -2 SD sampai dengan 1 SD, Gemuk: >1 SD sampai dengan 2 SD.

\section{HASIL PENELITIAN}

Berdasarkan tabel 1, menunjukkan bahwa karakteristik umur dari 94 responden umumnya berada pada kelompok umur 9 tahun sebanyak 50 orang siswa $(53,2 \%)$ dan hanya 1 orang yang berumur 12 tahun $(0,65 \%)$. Diketahui pula bahwa jumlah sampel perempuan $57(60,6 \%)$ lebih banyak dari sampel laki-laki 37 (39,4\%). Selain itu dapat dilihat bahwa sebagian besar responden baik ayah maupun ibu berlatar belakang pendidikan Perguruan Tinggi yaitu 64 responden $(68,1 \%)$ untuk pendidikan ayah dan54 responden ( 57,4\%) untuk pendidikan ibu. Diketahui pula bahwa pekerjaan ayah maupun ibu lebih banyak sebagai PNS yaitu 33 responden ( 35,1\%) untuk pekerjaan ayah dan 81 responden $(86,2 \%)$ untuk pekerjaan ibu.

Tabel 2 menunjukkan jika dari 94 responden yang menjadi sampel pada penelitian ini berdasarkan status gizi menurut indeks IMT/U terdapat $69(73,4 \%)$ siswa SDIT yang status gizi normal, 21 $(22,3 \%)$ status gizi gemuk dan sebanyak 4 (4,3\% siswa status gizi kurus. Dari 94 responden terdapat $61(64,9 \%)$ memiliki pengetahuan cukup tentang gizi seimbang dan sebanyak $33(35,1 \%)$ tentang gizi seimbang memiliki pengetahuan kurang. Terdapat 50 responden $(53,2 \%)$ yang memiliki pola makan baik dan $44(46,8 \%)$ sampel pola makan kurang.

Pengetahuan gizi pada responden umumnya sudah cukup di bagian pilar gizi seimbang. Adapun dalam penelitian ini pola makan yang dilihat adalah kebiasaan sarapan, jajan, konsumsi fast food dan konsumsi sayur dan buah. Kelima faktor tersebut merupakan pola konsumsi/makan yang umumnya dilakukan oleh anak usia sekolah dasar.

Pola makan yang sudah baik seperti kebiasaan sarapan setiap hari sebelum berangkat ke sekolah dan konsumsi buah dan sayur yang beragam setiap hari. Bagi anak-anak yang masih sekolah sarapan merupakan sumber energi membekali diri sebelum berangkat ke sekolah, dan energi tersebut digunakan untuk aktivitas dan belajar di sekolah Adapun pola makan yang kurang pada penelitian ini terlihat dari kebiasaan jajan di sekolah yang tinggi terutama pada anak yang melewatkan sarapan 
Tabel 2

Responden Berdasarkan Status Gizi, Menurut Indeks IMT/U, Pengetahuan Gizi Seimbang, dan Pola Makan

\begin{tabular}{lcc}
\hline Variabel & $\mathrm{n}$ & $\%$ \\
\hline Status Gizi & & 22,3 \\
Gemuk & 21 & 4,3 \\
Kurus & 4 & 73,4 \\
Normal & 69 & 64,9 \\
Pengetahuan Gizi Seimbang & 61 & 35,1 \\
Cukup & 33 & 53,2 \\
Kurang & & 46,8 \\
Pola Makan & 50 & \\
Baik & 54 & \\
Kurang & & \\
\hline
\end{tabular}

sebelum berangkat ke sekolah dan jenis jajanan yang dipilih seperti soft drink dan gorengan.

Tabel 3 menunjukkan hubungan antara pengetahuan dan status gizi yang diukur berdasarkan indek IMT/U dengan tingkat pengetahuan cukup sebanyak 61 responden yang terdiri dari gizi normal sebanyak 68,9\%, kategori gemuk sebesar $26,2 \%$ dan selebihnya kategori kurus sebesar 4,9\%. Uji statistik chi-square menunjukkan bahwa $P$-value berada pada angka 0,397 yang berarti tidak terdapat hubungan antara pengetahuan mengenai gizi seimbang dengan status gizi siswa.

Tabel 4 menunjukkan hasil bahwa terdapat 50 responden yang memiliki pola makan yang baik terdiri dari $70 \%$ yang memiliki status gizi normal, 26\% kategori gemuk, dan 4\% kategori kurus. Sebanyak 34 responden yang memiliki pola makan yang buruk terdiri dari 77,3\% gizi normal, $18,2 \%$ gemuk dan selebihnya $4,5 \%$ kategori gizi kurus. Hasil uji statistik chi-square menunjukkan bahwa tidak ada hubungan antara pola makan terhadap status gizi siswa dengan $P$-value berada pada angka 0,662.

\section{PEMBAHASAN}

Pengetahuan merupakan efek dari pengindraan manusia atau hasil pemahaman seseorang tentang objek dari indra mereka sendiri. Sebuah penginderaan yang menghasilkan pengetahuan sebagian besar merupakan efek perhatian dan pemahaman terhadap objek yang dimana sebagian besar pengetahuan diperoleh melalui persepsi auditori dan visual. Daya atau kemampuan yang dimiliki seseorang dalam mengingat kembali kandungan dan pemanfaatan zat gizi tersebut di dalam tubuh disebut dengan pengetahuan gizi. Derajat pengetahuan gizi yang dimiliki akan mempengaruhi sudut pandang dan tindakan dalam memilih makanan yang selanjutnya akan mempengaruhi kondisi tubuh. Pengetahuan gizi adalah kepandaian dalam memilih makanan yang menjadi sumber zat gizi dan kepandaian memilih jajanan yang sehat (Laenggeng \& Lumalang, 2015). Diharapkan terjadi peningkatan status gizi dengan adanya pengetahuan mengenai status gizi yang baik. Anak dengan pengetahuan gizi baik, memiliki perilaku makan yang lebih sehat dibandingkan dengan anak dengan pengetahuan gizi yang kurang (Fitri et al., 2020; 
Tabel 3

Analisis Hubungan Pengetahuan Dengan Status Gizi Indeks IMT/U

\begin{tabular}{|c|c|c|c|c|c|c|c|c|c|}
\hline \multirow{3}{*}{$\begin{array}{l}\text { Tingkat } \\
\text { Penge- } \\
\text { tahuan }\end{array}$} & \multicolumn{6}{|c|}{ Status Gizi berdasarkan IMT/U } & \multirow{2}{*}{\multicolumn{2}{|c|}{ Total }} & \multirow[t]{3}{*}{$P$} \\
\hline & \multicolumn{2}{|c|}{ Normal } & \multicolumn{2}{|c|}{ Gemuk } & \multicolumn{2}{|c|}{ Kurus } & & & \\
\hline & $\mathrm{N}$ & $\%$ & $\mathrm{~N}$ & $\%$ & $\mathrm{~N}$ & $\%$ & $\mathrm{~N}$ & $\%$ & \\
\hline Cukup & 42 & 68,9 & 16 & 26,2 & 3 & 4,9 & 61 & 100 & \\
\hline Kurang & 27 & 81,8 & 5 & 15,2 & 1 & 3 & 33 & 100 & 0,397 \\
\hline Total & 69 & 73,4 & 21 & 22,3 & 4 & 4,3 & 94 & 100 & \\
\hline
\end{tabular}

Asakura et al., 2017)

Penelitian ini juga menunjukkan bahwa responden dengan pengetahuan baik dan status gizi normal mendominasi dibanding responden dengan pengetahuan terkait gizi yang baik namun status gizi kategori gemuk. Adapun responden dengan pengetahuan terkait gizi yang masih kurang namun dengan status gizi normal dengan nilai signifikasi bahwa tidak ada hubungan yang signifikan antara pengetahuan gizi seimbang dan status gizi. Penelitian ini sesuai atau sejalan dengan penelitian. Noviyanti \& Marfuah (2017), Nova \& Yanti (2018), Jannah \& Kusumaningrum, (2021), dan Muliawati \& Mardiyati (2018) yang mendapatkan hasil bahwa tidak didapatkan hubungan antara pengetahuan siswa terkait gizi seimbang dengan status gizi yang dimiliki. Baik atau tidaknya pengetahuan gizi bukan menjadi dasar dalam memilih makanan bergizi, melainkan adanya faktor daya beli dan kebiasaan.
Alasan lain kurangnya hubungan antara pengetahuan terkait gizi seimbang dan status gizi dikarenakan pengetahuan tidak memiliki dampak secara langsung terhadap status gizi. Dengan bertambahnya umur anak, maka pemeberian makanan harus lebih beragam, bergizi serta seimbang demi menunjang tumbuh kembang anak serta status gizinya. Orang tua sangat berperan penting dalam menentukan jenis makanan yang akan diperoleh oleh anak. Pola makan yang dikonsumsi dan memadai berhubungan dengan kualitas konsumsi makanan anak yang baik dan akan meningkatkan kecukupan zat gizi pula pada akhirnya (Lister et al., 2017). Faktor utama dari buruknya gizi seseorang adalah penyakit infeksi dan asupan gizi (Farhadi \& Ovchinnikov, 2018; Ndemwa et al., 2017). Adapun pemicu tidak langsung (indirect) permasalahan gizi adalah pelayanan keperawatan dan kesehatan anak dan ibu hamil (Aoun et al., 2015; Dominguez,et al., 2018). Selain

\section{Tabel 4}

Analisis Hubungan Pola Makan Dengan Status Gizi Indeks IMT/U

\begin{tabular}{|c|c|c|c|c|c|c|c|c|c|}
\hline \multirow{3}{*}{$\begin{array}{l}\text { Pola } \\
\text { makan }\end{array}$} & \multicolumn{6}{|c|}{ Status Gizi berdasarkan IMT/U } & \multirow{2}{*}{\multicolumn{2}{|c|}{ Total }} & \multirow{3}{*}{$P$} \\
\hline & \multicolumn{2}{|c|}{ Normal } & \multicolumn{2}{|c|}{ Gemuk } & \multicolumn{2}{|c|}{ Kurus } & & & \\
\hline & $\mathrm{N}$ & $\%$ & $\mathrm{~N}$ & $\%$ & $\mathrm{~N}$ & $\%$ & $\mathrm{~N}$ & $\%$ & \\
\hline Baik & 35 & 70 & 13 & 26 & 2 & 4 & 50 & 100 & \\
\hline Buruk & 34 & 77,3 & 8 & 18,2 & 2 & 4,5 & 44 & 100 & 0,662 \\
\hline Total & 69 & 73,4 & 21 & 22,3 & 4 & 4,3 & 94 & 100 & \\
\hline
\end{tabular}


pengetahuan, masalah utama juga mencakup pendidikan orang tua hingga krisis ekonomi yang mendesak (Shinsugi et al., 2019; Shen et al., 2015).

Penelitian ini tidak sejalan dengan hasil temuan yang dipublikasikan oleh Kigaru et al. (2015) anak-anak usia sekolah memiliki pengetahuan gizi sedang dan praktik diet yang buruk, terkait dengan sikap diet negatif. Penelitian lain yang dilakukan oleh Renata dan Dewajanti (2017) yang menemukan bahwa terdapat hubungan antara pengetahuan gizi, perilaku, dan sikap anak sekolah dengan status gizi siswa SD Tarakanita Gading Serpong. Pengetahuan gizi tanpa diikuti kemauan, sikap yang baik, serta keterampilan untuk bertindak tidak akan membawa perubahan pada status gizi anak.

Pola makan adalah cara kerja yang mengorganisir kuantitas dan ragam makanan yang akan dikonsumsi untuk tujuan tertentu, seperti menjaga kesehatan, status gizi, serta pencegahan maupun penyembuhan penyakit. Pola makan ditentukan dengan berbagai cara, termasuk mengevaluasi tingkat penggunaan bahan makanan serta asupan yang diperlukan oleh tubuh. Frekuensi penggunaan makanan cenderung lebih kepada memilih makanan yang akan dimakan sehari-hari, dan asupan gizi merupakan dampak langsung dari aktivitas pemilihan makanan. Kebiasaan makan yang teratur namun sesuai porsi dapat menjaga peningkatan status gizi. Kekurangan gizi merupakan akibat manusia kurangnya zat gizi yang diperlukan oleh tubuh, seperti asupan zat gizi yang tidak mencukupi, kualitas yang rendah, dan frekuensi makan yang tid- ak mencukupi (Noviani et al., 2016).

Hasil penelitian menunjukkan bahwa lebih banyak responden cenderung dengan pola makan yang baik dibanding dengan pola makan kurang. Ini menunjukkan lebih dari separuh responden dan utamanya orang tua masih memberikan perhatian terhadap pola makan anaknya. Namun hal ini tidak mutlak membuat siswa SDIT Kota Makassar masih terbebas dari masalah pemenuhan makanan. Terbukti dengan data yang menunjukkan bahwa hampir separuh sampel masih memiliki pola makan yang kurang.

Data yang telah diperoleh tersebut memperlihatkan bahwasanya sampel dengan pola makan yang baik berada pada status gizi normal. Faktor pencetusnya adalah orang tua masih memperhatikan pemenuhan makanan anaknya serta memberikan makanan di waktu yang tepat. Hasil penelitian menunjukkan bahwa tidak didapatkan kaitan yang bermakna antara pola makan dan status gizi. Hasil penelitian ini berbeda dengan penelitian yang dilakukan Boo et al. (2015) pada anak SD di Jeju, Korea dan Zhang et al. (2017) pada remaja di China yang menemukan adanya kaitan antara pola makan dengan status gizi anak.

Pada penelitian ini, status gizi yang multifaktor menjadi salah satu penyebab tidak ditemukannya keterkaitan antara pola makan dan status gizi itu sendiri. Status gizi seseorang tidak hanya disebabkan oleh pola makannya, tetapi juga berinteraksi dengan faktor lain. Dalam penelitian ini variabel asupan makanan, penyakit infeksi tidak dijadikan sebagai variabel, sedangkan varia- 
bel-variabel tersebut berpengaruh langsung terhadap status gizi. Kecenderungan anak yang memiliki penyakit infeksi adalah status gizinya kurang disebabkan karena penyerapan asupan zat gizi makanan tidak optimal di dalam tubuh (Oktafiana \& Wahini, 2016).

Hasil penelitian ini sesuai dan mendukung penelitian yang dilakukan Sholikah et al., (2017), Panjaitan et al. (2018), dan Octaviani et al. (2018) yang memaparkan bahwa tidak terdapat korelasi yang signifikan status gizi anak dengan pola makannya. Sedangkan pada penelitian Rahmayanti dan Astika (2016), Sinamora (2016), dan Afrilia (2018) menunjukkan hubungan antara pola makan dan status gizi. Faktor seperti kemampuan keluarga dalam menyediakan makanan yang masih sangat rendah merupakan pengaruh yang lebih mendominasi. Faktor lain yang ada pengaruhnya dengan status gizi anak adalah adanya penyakit menular dan kondisi sanitasi yang kurang baik. Masalah gizi anak terutama disebabkan oleh tidak seimbangnya asupan dan zat gizi yang dikeluarkan oleh tubuh (nutrient imbalance) dan adanya alternatif kesalahan pada penentuan atau pemilihan bahan-bahan yang akan dikonsumsi (Dipasquale et al., 2020). Meskipun pola makan anak tidak mencukupi, kemungkinan status gizi anak baik tidak dikesampingkan. Walaupun dalam praktiknya kuantitas pemberian makanan oleh orang tua hanya sebanyak dua kali dalam sehari, namun komposisi makanan, jumlah makanan yang diberikan, serta kandungan zat gizi yang dibutuhkan tubuh dapat terpenuhi. Hal tersebut menjadi salah satu alasan anak memiliki status gizi yang baik.

\section{KESIMPULAN}

Umumnya siswa Sekolah Dasar Islam Terpadu (SDIT) di Kota Makassar memiliki pengetahuan yang cukup mengenai pilar gizi seimbang. Status gizi siswa Sekolah Dasar Islam Terpadu (SDIT) berdasarkan pengukuran antropometri di Kota Makassar sebagian besar berada gizi normal dan memiliki pola makan yang baik. Tidak ditemukan adanya hubungan antara pengetahuan gizi seimbang dan pola makan siswa terhadap status gizi siswa Sekolah Dasar Islam Terpadu (SDIT) di Kota Makassar.

Peneliti menawarkan adanya program duta gizi seimbang di setiap sekolah. Duta gizi seimbang ini nantinya akan dilatih terkait gizi seimbang dan bertanggung jawab mensosialisasikan pesan-pesan gizi seimbang kepada teman sekolah, maupun di keluarga agar semakin meningkatkan pengetahuan yang sudah ada dan tetap menjaga pola makan yang baik. Dinas pendidikan dapat bekerja sama dengan perguruan tinggi dan dinas kesehatan dalam program duta gizi seimbang. Mekanisme pemilihan duta gizi seimbang ini dilakukan oleh masing-masing sekolah dan setiap anak berhak mengikuti ajang pemilihan ini dengan kriteria tertentu (sehat, berstatus gizi baik serta memiliki pola makan yang baik). Siswa yang menjadi duta gizi seimbang dapat diberi reward oleh Pemda melalui dinas pendidikan berupa beasiswa selama menjadi duta gizi seimbang. 


\section{DAFTAR PUSTAKA}

Afrilia, D. A. (2018). Hubungan Pola Makan Dan Aktifitas Fisik Terhadap Status Gizi Di Siswa Smp Al-Azhar Pontianak. Pontianak Nutrition Journal (PNJ), 1(1), 10-13. https:// doi.org/10.30602/pnj.v1i1.277

Al Yazeedi, B., Berry, D. C., Crandell, J., \& Waly, M. (2021). Family influence on children's nutrition and physical activity patterns in Oman. Journal of Pediatric Nursing, 56, e42e48. https://doi.org/10.1016/ j.pedn.2020.07.012

Ali, B. M., Mohammed, S., Akram, S., Salar, S., Baxtiar, L., Ismail, L., \& Nawzad, S. (2020). Knowledge, Attitude and Practice of Medical Students of Sulaimani Regarding Modern Lifestyle And Its Effect On Health. Kurdistan Journal of Applied Research, 49-62. https://doi.org/10.24017/science.2020.ICHMS 2020.6

Amrah, A. (2013). Perkembangan Moral Anak Usia Sekolah Dasar. Publikasi Pendidikan, 3(1). https://doi.org/10.26858/publikan.v3i1.1602

Aoun, N., Matsuda, H., \& Sekiyama, M. (2015). Geographical accessibility to healthcare and malnutrition in Rwanda. Social science \& medicine, 130, 135-145. https://doi.org/10.1016/j.socscimed.2015.02.0 04

Asakura, K., Todoriki, H., \& Sasaki, S. (2017). Relationship between nutrition knowledge and dietary intake among primary school children in Japan: Combined effect of children's and their guardians' knowledge. Journal of epidemiology, 27(10), 483-491. https://doi.org/10.1016/j.je.2016.09.014

Bagchi, T. (2014). Traditional food \& modern lifestyle: Impact of probiotics. The Indian journal of medical research, 140(3), 333. https://www.ncbi.nlm.nih.gov/pmc/articles/P MC4248377/

Boo, M. N., Cho, S. K., \& Park, K. (2015). Evaluation of dietary behavior and nutritional status of elementary school students in Jeju using nutrition quotient. Journal of Nutrition and Health, 48(4), 335-343. https://doi.org/10.4163/jnh.2015.48.4.335

Calder, P. C., Carr, A. C., Gombart, A. F., \& Eggersdorfer, M. (2020). Optimal nutritional status for a well-functioning immune system is an important factor to protect against viral infec- tions. Nutrients, 12(4), 1181. https://doi.org/10.3390/nu12041181

Corvalán, C., Garmendia, M. L., Jones $\square$ Smith, J., Lutter, C. K., Miranda, J. J., Pedraza, L. S., \& Stein, A. D. (2017). Nutrition status of children in Latin America. Obesity Reviews, 18, 7-18. https://doi.org/10.1111/obr.12571

Couteau, J. (2020). Hubungan antara Pengetahuan, Sikap dan Perilaku Gizi Seimbang Ibu dengan Status Gizi Anak SD Budya Wacana Yogyakarta [Thesis, Universitas Kristen Duta Wacana]. https://katalog.ukdw.ac.id/4026/

Cuenca, M. H., Proaño, G. V., Blankenship, J., Cano-Gutierrez, C., Chew, S. T., Fracassi, P., \& Steiber, A. (2020). Building Global Nutrition Policies in Health Care: Insights for Tackling Malnutrition from the Academy of Nutrition and Dietetics 2019 Global Nutrition Research and Policy Forum. Journal of the Academy of Nutrition and Dietetics, 120(8), 1407-1416. https://doi.org/10.1016/j.jand.2020.03.011

Dipasquale, V., Cucinotta, U., \& Romano, C. (2020). Acute Malnutrition in Children: Pathophysiology, Clinical Effects and Treatment. Nutrients, 12(8), 2413. https://doi.org/10.3390/nu12082413

Dominguez, V. A. H., \& Halili, B. L. B. (2018). Food for Thought: The Socioeconomic Impact of Child Malnutrition and Maternal Health on the Academic Performance of Filipino School Children. European Journal of Sustainable Development, 7(4), 361-361. https://doi.org/10.14207/ejsd.2018.v7n4p361

Donin, A. S., Nightingale, C. M., Owen, C. G., Rudnicka, A. R., Cook, D. G., \& Whincup, P. H. (2018). Takeaway meal consumption and risk markers for coronary heart disease, type 2 diabetes and obesity in children aged 9-10 years: a cross-sectional study. Archives of disease in childhood, 103(5), 431-436. http://dx.doi.org/10.1136/archdischild-2017312981

Fadila, R. N., Amareta, D. I., \& Febriyatna, A. (2017). Hubungan Pengetahuan Dan Perilaku Ibu Tentang Gizi Seimbang Dengan Status Gizi Anak Tk Di DesaYosowilangun Lor Kabupaten Lumajang. Jurnal Kesehatan, 5(1), 14-20. https://doi.org/10.25047/j-kes.v5i1.26

Fajriani, F., Aritonang, E. Y., \& Nasution, Z. (2020). Hubungan Pengetahuan, Sikap dan Tindakan Gizi Seimbang Keluarga dengan Status Gizi Anak Balita Usia 2-5 Tahun. Jurnal Ilmu 
Kesehatan Masyarakat, 9(01), 1-11. https://doi.org/10.33221/jikm.v9i01.470

Farhadi, S., \& Ovchinnikov, R. S. (2018). The relationship between nutrition and infectious diseases: A review. Biomedical and Biotechnology Research Journal (BBRJ), 2(3), 168. https://www.doi.org/10.4103/bbrj.bbrj_69_1 8

Fitri, Y., Al Rahmad, A. H., Suryana, S., \& Nurbaiti, N. (2020). Pengaruh penyuluhan gizi tentang jajanan tradisional terhadap peningkatan pengetahuan dan perilaku jajan anak sekolah. AcTion: Aceh Nutrition Journal, 5(1), 13-18. http://dx.doi.org/10.30867/action.v5i1.186

Ijarotimi, O. S. (2013). Determinants of childhood malnutrition and consequences in developing countries. Current Nutrition Reports, 2(3), 129-133. https://doi.org/10.1007/s13668013-0051-5

Irnani, H., \& Sinaga, T. (2017). Pengaruh pendidikan gizi terhadap pengetahuan, praktik gizi seimbang dan status gizi pada anak Sekolah Dasar. Jurnal Gizi Indonesia (The Indonesian Journal of Nutrition), 6(1), 58-64. https://doi.org/10.14710/jgi.6.1.58-64

Jannah, M., \& Kusumaningrum, I. (2021). Analisis Obesitas pada Anak Sekolah Dasar Berdasarkan Pengetahuan, Sikap, dan Paparan Informasi tentang Gizi Seimbang. ARTERI: Jurnal Ilmu Kesehatan, 2(3), 67-73. https://doi.org/10.37148/arteri.v2i3.168

Kementerian Kesehatan RI. (2014). Laporan Hasil Riset Kesehatan Dasar (Riskesdas). Badan Litbangkes Kementerian Kesehatan RI. https://www.litbang.kemkes.go.id/laporanriset-kesehatan-dasar-riskesdas/

Kigaru, D. M. D., Loechl, C., Moleah, T., Macharia-Mutie, C. W., \& Ndungu, Z. W. (2015). Nutrition knowledge, attitude and practices among urban primary school children in Nairobi City, Kenya: a KAP study. BMC Nutrition, 1(1), 1-8. https://doi.org/10.1186/s40795-015-0040-8

Kumar, S., \& Preetha, G. S. (2012). Health promotion: an effective tool for global health. Indian journal of community medicine: official publication of Indian Association of Preventive \& Social Medicine, 37(1), 5. https://dx.doi.org/10.4103\%2F09700218.94009
Laenggeng, A. H., \& Lumalang, Y. (2015). Hubungan Pengetahuan Gizi dan Sikap Memilih Makanan Jajanan dengan Status Gizi Siswa SMP Negeri 1 Palu. Healthy Tadulako Journal (Jurnal Kesehatan Tadulako), 1(1), 4957. https://doi.org/10.22487/htj.v1i1.6

Lister, N. B., Gow, M. L., Chisholm, K., Grunseit, A., Garnett, S. P., \& Baur, L. A. (2017). Nutritional adequacy of diets for adolescents with overweight and obesity: considerations for dietetic practice. European journal of clinical nutrition, 71(5), 646-651. https://doi.org/10.1038/ejcn.2016.268

Liszewska, N., Scholz, U., Radtke, T., Horodyska, K., Liszewski, M., \& Luszczynska, A. (2018). Association between children's physical activity and parental practices enhancing children's physical activity: The moderating effects of children's BMI z-score. Frontiers in psychology, $8, \quad 2359$. https://doi.org/10.3389/fpsyg.2017.02359

Lonto, J. S., Umboh, A., \& Babakal, A. (2019). Hubungan pola asuh orang tua dengan perilaku jajan anak usia sekolah (9-12 Tahun) di SD Gmim Sendangan Sonder. Jurnal Keperawatan, $\quad 7(1)$. https://ejournal.unsrat.ac.id/index.php/jkp/art icle/view/24338

Mavrovouniotis, F. (2012). Inactivity in childhood and adolescence: a modern lifestyle associated with adverse health consequences. Sport Science Review, 21(3-4), 75. https://doi.org/10.2478/v10237-012-0011-9

Muliawati, R. R., \& Mardiyati, N. L. (2018). Hubungan Pengetahuan Memilih Makanan Jajanan dan Jumlah Uang Saku dengan Status Gizi Siswa SD Negeri Kleco II Surakarta (Doctoral dissertation, Universitas Muhammadiyah Surakarta). http://eprints.ums.ac.id/66841/

Ndemwa, M., Wanyua, S., Kaneko, S., Karama, M., \& Anselimo, M. (2017). Nutritional status and association of demographic characteristics with malnutrition among children less than 24 months in Kwale County, Kenya. The Pan African Medical Journal, 28. https://dx.doi.org/10.11604\%2Fpamj.2017.2 8.265.12703

Nova, M., \& Yanti, R. (2018). Hubungan Asupan Zat Gizi Makro dan Pengetahuan Gizi dengan Status Gizi pada Siswa Mts. s Annurkota Padang. JURNAL KESEHATAN 
PERINTIS (Perintis's Health Journal), 5(2), 169-175.

https://doi.org/10.33653/jkp.v5i2.145

Noviani, K., Afifah, E., \& Astiti, D. (2016). Kebiasaan jajan dan pola makan serta hubungannya dengan status gizi anak usia sekolah di SD Sonosewu Bantul Yogyakarta. Jurnal Gizi Dan Dietetik Indonesia (Indonesian Journal Of Nutrition And Dietetics), 4(2), 97-104. http://dx.doi.org/10.21927/ijnd.2016.4(2).97104

Noviyanti, R. D., \& Marfuah, D. (2017). Hubungan pengetahuan Gizi, Aktivitas fisik, dan pola makan terhadap status gizi remaja di kelurahan purwosari Laweyan Surakarta. URECOL, 421-426. https://journal.unimma.ac.id/index.php/urecol/ article/view/1059

Octaviani, P., Izhar, M. D., \& Amir, A. (2018). Hubungan Pola Makan Dan Aktivitas Fisik Dengan Status Gizi Pada Anak Sekolah Dasar Di SD Negeri 47/IV Kota Jambi. Jurnal Kesmas Jambi, 2(2), 56-66. https://doi.org/10.22437/jkmj.v2i2.6554

Oktafiana, R., \& Wahini, M. (2016). Faktor-Faktor Yang Mempengaruhi Status Gizi Anak Usia Sekolah Pada Keluarga Atas Dan Bawah (Kasus Di Desa Sidoharjo, Kabupaten Ponorogo). Jurnal Tata Boga, 5(3). https://core.ac.uk/download/pdf/230743030.p df

Panjaitan, W. F., Siagian, M., \& Hartono, H. (2019). Hubungan Pola Makan dengan Status Gizi Pada Anak Sekolah Dasar Al Hidayah Terpadu Medan Tembung. Jurnal Dunia Gizi, 2(2), 71-78. https://doi.org/10.33085/jdg.v2i2.4448

Passos, D. R. D., Gigante, D. P., Maciel, F. V., \& Matijasevich, A. (2015). Children's eating behavior: comparison between normal and overweight children from a school in Pelotas, Rio Grande do Sul, Brazil. Revista Paulista de Pediatria, 33(1), 42-49. https://doi.org/10.1016/j.rpped.2014.11.007

Pattola, P., Nur, A., Atmadja, T. F. A. G., Yunianto, A. E., Rasmaniar, R., Marzuki, I., \& Purba, A. M. V. (2020). Gizi Kesehatan dan Penyakit. Yayasan Kita Menulis.

Pereira, P. F., Rita de Cássia, G. A., \& Araújo, R. M. A. (2014). Does breastfeeding influence the risk of developing diabetes mellitus in chil- dren? A review of current evidence. Jornal de pediatria, $\quad 90(1), \quad 7-15$. https://doi.org/10.1016/j.jped.2013.02.024

Rahmayanti, D., \& Astika E. (2016). Pola Makan Anak Dengan Status Gizi Anak Usia 6-8 Tahun Di SD Wilayah Kelurahan Cempaka. Dunia Keperawatan: Jurnal Keperawatan dan Kesehatan, 4(1), 8-13. http://dx.doi.org/10.20527/dk.v4i1.2504

Renata, P., \& Dewajanti, A. M. (2017). Hubungan Pengetahuan, Sikap, dan Perilaku Tentang Gizi Seimbang dengan Status Gizi Siswa Kelas IV dan V di Sekolah Dasar Tarakanita Gading Serpong. Jurnal Kedokteran Meditek. 23(61). https://doi.org/10.36452/jkdoktmeditek.v23i6 1.1460

Shen, X., Gao, X., Tang, W., Mao, X., Huang, J., \& Cai, W. (2015). Food insecurity and malnutrition in Chinese elementary school students. British Journal of Nutrition, 114(6), 952-958. https://doi.org/10.1017/S0007114515002676

Shinsugi, C., Gunasekara, D., Gunawardena, N. K., Subasinghe, W., Miyoshi, M., Kaneko, S., \& Takimoto, H. (2019). Double burden of maternal and child malnutrition and socioeconomic status in urban Sri Lanka. PloS one, 14(10), e0224222. https://doi.org/10.1371/journal.pone.0224222

Sholikah, A. S., Rustiana, E. R., \& Yuniastuti, A. (2017). Faktor-faktor yang berhubungan dengan status gizi balita di pedesaan dan perkotaan. Public Health Perspective Journal, 2(1). https://journal.unnes.ac.id/nju/index.php/phpj/ article/view/10993

Simamora, H. (2016). Pola Makan Dan Status Gizi Pada Anak Etnis Cina Di Sd Sutomo 2 Dan Anak Etnis Batak Toba Di Sd Antonius Medan Tahun 2014. Elisabeth Health Jurnal, 1(2), 27-36. https://doi.org/10.52317/ehj.v1i2.197

Tette, E. M., Sifah, E. K., \& Nartey, E. T. (2015). Factors affecting malnutrition in children and the uptake of interventions to prevent the condition. BMC pediatrics, 15(1), 1-11. https://doi.org/10.1186/s12887-015-0496-3

World Health Organization. (2016). Global Health Observatory data repository. Unicef. https://apps.who.int/gho/data/view.main.NUT UNUNDERWEIGHTv?lang=en 
Zhang, Q., Chen, X., Liu, Z., Varma, D. S., Wan, R., \& Zhao, S. (2017). Diet diversity and nutritional status among adults in southwest China. PloS one, 12(2), e 0172406. https://doi.org/10.1371/journal.pone.0172406 